\title{
Echinoderm Microtubule-Associated Protein-Like 4
}

National Cancer Institute

\section{Source}

National Cancer Institute. Echinoderm Microtubule-Associated Protein-Like 4. NCI

Thesaurus. Code C71005.

Echinoderm microtubule-associated protein-like 4 (981 aa, $109 \mathrm{kDa}$ ) is encoded by the human EML4 gene. This protein may play a role in the modification of microtubule assembly dynamics. 